\title{
Kajian Kualitas Air Sumur Gali dan Perilaku Masyarakat di Sekitar Pabrik Semen Kelurahan Karangtalun Kecamatan Cilacap Utara Kabupaten Cilacap
}

\author{
Dhani Hapsari \\ Program Pascasarjana Universitas Jendral Soedirman Purwokerto \\ Email: d.hap18@yahoo.co.id
}

\begin{abstract}
Abstrak
Tujuan penelitian ini adalah untuk mengkaji kualitas air sumur gali warga di sekitar pabrik semen, mengkaji perilaku masyarakat dan menganalisis hubungan perilaku masyarakat dengan kualitas air sumur gali di Kelurahan Karangtalun. Penelitian dilaksanakan pada survey skala, adalah kualitas air sumur dianalisis dengan Metode Storet dan perilaku masyarakat secara purposive random sampling dengan kuesioner. Hasil penelitian menunjukkan bahwa kualitas air sumur gali di Kelurahan Karangtalun tercemar ringan hingga tercemar berat, terutama pada Stasiun I, V, dan XIII yang berada pada kondisi "cemar berat". Masyarakat Kelurahan Karangtalun memiliki pengetahuan yang cukup, bersikap negative dan bertindak aktif sehingga perilaku masyarakat secara umum adalah berperilaku netral mengenai keberadaan tempat penyimpanan kapur. Kualitas air sumur gali di Kelurahan Karangtalun sebagian besar tercemar sedang dan perilaku masyarakat cenderung netral. Hasil analisa Chi - Square menunjukkan bahwa nilai Sig 0,506 > 0,05 maka Ho ditolak, sehingga antara kualitas air sumur gali dengan perilaku masyarakat tidak ada hubungan. Sebaiknya kajian kualitas air sumur gali dilakukan pula pada musim hujan untuk diperoleh perbandingan hasil pengamatan.
\end{abstract}

Kata Kunci : kualitas air, sumur gali, perilaku masyarakat, storet

\section{PENDAHULUAN}

Peraturan Pemerintah No. 82 Tahun 2001 menyebutkan air adalah semua air yang terdapat di atas dan di bawah permukaan tanah, kecuali air laut dan air fosil. Peraturan Pemerintah tersebut juga menjelaskan bahwa air merupakan salah satu sumber daya alam yang memiliki fungsi sangat penting bagi kehidupan dan perikehidupan manusia, serta untuk memajukan kesejahteraan umum, sehingga merupakan modal dasar dan faktor utama pembangunan. Berdasarkan definisi dan penjelasan mengenai air tersebut diketahui bahwa air memegang peranan yang sangat penting dalam kehidupan makhluk hidup. Dalam kehidupan sehari-hari, air dipergunakan antara lain untuk keperluan minum, mandi, memasak, mencuci, membersihkan rumah, pelarut obat, dan pembawa bahan buangan industri (Sutrisno, 2004).

Air bersih berupa air tawar mempunyai peran yang sangat penting dalam kehidupan manusia antara lain untuk minum, mengolah makanan, mandi, energi, transportasi, pertanian, industri, dan rekreasi. Jumlah air yang terbatas dan semakin banyaknya manusia menyebabkan terjadinya krisis air bersih, kualitas air tawar yang ada pun semakin rusak. Perebutan penggunaan air bersih untuk berbagai penggunaan menyebabkan hilangnya akses yang layak terhadap air bersih bagi sebagian orang. 
Perilaku boros air bersih menyebabkan semakin banyak lagi orang yang kehilangan akses terhadap air bersih.

Kelangkaan air muncul di daerah tertentu dan air mengalami degradasi kualitas yang mengancam dan menghambat pembangunan ekonomi di masa depan. Terdapat hubungan antara penggunaan lahan misalnya untuk aktivitas perkotaan dan industri dengan ketersediaan air bersih. Kontrol yang dilakukan terhadap penggunaan lahan yang menyebabkan pencemaran air akibat kegiatan-kegiatan tersebut masih rendah. Kebutuhan air bersih dari waktu ke waktu meningkat dengan pesat, sejalan dengan bertambahnya jumlah penduduk dan meningkatnya kegiatan manusia sesuai dengan tuntutan kehidupan yang terus berkembang untuk mencukupi berbagai keperluan (Asmadi, et.al., 2011).

Sumber air merupakan salah satu komponen utama yang ada pada suatu sistem penyediaan air bersih, karena tanpa sumber air maka suatu sistem penyediaan air bersih tidak akan berfungsi (Sutrisno, 2000). Macam-macam sumber air dapat di manfaatkan sebagai sumber air bersih antara lain air laut, air hujan, air permukaan (sungai, rawa, danau) dan air tanah yang salah satunya dengan sumur gali (Asmadi, et al., 2011). Sumur gali adalah satu konstruksi sumur yang paling umum dan banyak digunakan untuk mengambil air tanah bagi masyarakat kecil dan rumah - rumah perorangan sebagai air minum dengan kedalaman 7-10 meter dari permukaan tanah (Gabriel, 2001).

Penelitian yang dilakukan oleh Harmayani dan Konsukartha (2007) menunjukkan bahwa saluran air / drainase yang tidak berfungsi dengan baik. Karena saluran tersebut tersumbat oleh sampah dan pembuangan air limbah dapur langsung ke tanah mengakibatkan terjadinya pencemaran sumur gali sehingga sebagian besar air sumur gali tercemar oleh bakteri Eschericia Coli dan bakteri Coliform. Sedangkan air sumur yang berasal dari air sumur bor tidak mengalami pencemaran oleh bakteri, sehingga air sumur bor dapat dikonsumsi menjadi air minum. Hal ini menunjukkan bahwa sumur gali mudah terkontaminasi oleh bakteri dari sumber pencemaran seperti limbah rumah tangga dan sisa pembuangan manusia karena sumur gali tidak kedap air. Air mudah meresap dan melewati pori-pori tanah sehingga bercampur dengan materi lain sehingga jika air limbah atau air yang sudah tercemar melewati pori-pori tanah dapat mencemari sumber air yang masih bersih. Air sumur gali juga dapat tercemar karena adanya aktivitas industri, misalnya karena air limbah yang meresap ke dalam sumur melalui pori-pori tanah, tumpahan bahan berbahaya yang mengalir ke lingkungan, bahan baku industri yang mudah terurai dan mencemari lingkungan dan sebagainya. Kondisi 
tersebut sangat membahayakan terutama jika ada letak indutri tidak jauh dari pemukiman penduduk karena dapat mengganggu kesehatan.

Salah satu kawasan yang merupakan kompleks industri dan sekaligus dekat dengan kawasan penduduk yaitu Kelurahan Karangtalun yang terletak di Kabupaten Cilacap. Industri yang ada saat ini ada di kawasan tersebut adalah industri semen PT. Holcim Indonesia yang telah berdiri dan aktif melakukan kegiatan pertambangan sejak tahun 1971. Proses produksi secara khusus terdiri dari 4 tahap yaitu penggilingan bahan baku, pembakaran, penggilingan akhir dan pengantongan semen. Kegiatan pembakaran dalam proses produksi merupakan proses inti, karena sebagian besar energi diperlukan dalam proses ini. Ditinjau dari pengaruh lingkungan, maka proses pembakaran termasuk salah satu yang paling berpotensi (disamping juga kegiatan penambangan) dalam mempengaruhi kualitas lingkungan (Bertschinger, 2006).

Berdasarkan hasil observasi pada 1 Oktober 2013 dan Laporan Pembangunan Berkelanjutan PT. Holchim Indonesia pada 2010, diketahui bahwa pabrik didirikan tidak jauh dari area penambangan bahan baku utama yaitu batu kapur. Batu kapur (limestone) adalah batuan sedimen terutama terdiri dari kalsium karbonat $\left(\mathrm{CaCO}_{3}\right)$ dalam bentuk kalsit mineral. Batuan ini paling sering terbentuk di perairan laut yang dangkal dan merupakan batuan sedimen organik yang terbentuk dari akumulasi cangkang hewan, karang, alga dan puing-puing. Batu kapur mengandung 98,9\% kalsium karbonat $\left(\mathrm{CaCO}_{3}\right)$ dan 0,95\% magnesium karbonat $\left(\mathrm{MgCO}_{3}\right)$ (Russell, 2007).

Wilayah Karangtalun dimana PT. Holchim yang merupakan industri semen dengan bahan baku utama yaitu batu kapur (gamping) menyebabkan air pada sumur gali di sekitar industri terkontaminasi kandungan kapur. Survei awal terhadap sampel air sumur gali di Kelurahan Karangtalun yang dekat dengan area penyimpanan (gudang) bahan baku kapur mengandung kadar kapur $\left(\mathrm{CaCO}_{3}\right)$ sangat tinggi. Hasil pengujian laboratorium pada tanggal 3 Oktober 2013 menunjukkan bahwa air sumur gali di Kelurahan Karangtalun mengandung $\mathrm{CaCO}_{3}$ sebanyak 598,5 mg/l (598,5 ppm), sedangkan dalam Peraturan Menteri Kesehatan Republik Indonesia Nomor 416/MENKES/PER/IX/1990 menetapkan bahwa kadar $\mathrm{CaCO}_{3}$ maksimal adalah 500 mg/l (500 ppm), hal ini berarti kandungan kapur yang ada dalam sumur gali melebihi ambang batas yang telah ditentukan. Kadar kapur yang berlebihan dalam air membuat air mengalami kesadahan atau disebut air sadah. Air sadah memberikan dampak antara lain dampak terhadap kesehatan yaitu dapat menyebabkan cardiovascular (penyumbatan darah jantung) dan urolithiasis (batu ginjal), menyebabkan pengerakan pada peralatan logam untuk memasak sehingga penggunaan energi 
menjadi boros, penyumbatan pada pipa logam karena endapan $\mathrm{CaCO}_{3}$, dan pemakaian sabun menjadi lebih boros karena buih yang dihasilkan sedikit.

Wilayah tersebut tersebut terdiri dari 9 RW dan 6 RT dengan rata - rata 4 warga setiao KK-nya (BPS, 2013). Dampak positif atau negatif dapat dirasakan oleh warga sekitar industri. Dampak positifnya yaitu dengan keberadaan PT. Holchim tersebut maka terbuka peluang bagi penduduk wilayah sekitar industri terutama di Karangtalun untuk terlibat dalam kegiatan industri seperti menjadi pekerja atau buruh di pabrik. Dampak negatifnya adalah adanya pencemaran lingkungan akibat paparan bahan dari industri seperti batu kapur yang dapat mengganggu kesehatan. Kondisi air sumur yang tercemar tersebut dapat menimbulkan reaksi dan tindakan tertentu dari masyarakat Karangtalun karena akses air bersih yang menurun. Aksi-reaksi suatu kelompok manusia terhadap lingkungan tersebut disebut dengan perilaku masyarakat. Hal inilah yang menarik bagi peneliti untuk mengkaji lebih lanjut mengenai kualitas air sumur gali dan perilaku masyarakat terhadap adanya gudang kapur sebagai area penyimpanan bahan bahan baku kapur di kecamatan Karangtalun, Kecamatan Cilacap Utara, Kabupaten Cilacap.

\section{METODE PENELITIAN}

\subsection{Materi dan Sasaran Penelitian}

\subsubsection{Materi Penelitian}

Materi penelitian dalam penelitian ini adalah air sumur gali dan masyarakat Kelurahan Karangtalun, Kecamatan Cilacap Utara, Kabupaten Cilacap.

\subsubsection{Sasaran Penelitian}

Mengidentifikasi kualitas air sumur gali (fisika, kimia dan biologi) yang dihasilkan oleh rembesan tempat penyimpanan kapur dan menelaah perilaku masyarakat di Kelurahan Karangtalun, Kecamatan Cilacap Utara, Kabupaten Cilacap.

\subsection{Metode Pengambilan Sampel}

Penelitian ini dilaksanakan dengan menggunakan metode survai pada kualitas air sumur dan perilaku masyarakat di Kelurahan Karangtalun, Kecamatan Cilacap Utara, Kabupaten Cilacap. 
Pengambilan sampel untuk kualitas air sumur dilakukan pada empat belas stasiun pengamatan, yaitu :

1. Stasiun I berada di belakang sebelah kanan tempat penyimpanan yang berjarak 10 meter

2. Stasiun II berada di belakang sebelah kanan tempat penyimpanan yang berjarak 15 meter

3. Stasiun 3. Stasiun III berada di belakang sebelah kiri tempat penyimpanan yang berjarak 25 meter

4. Stasiun IV berada tepat di belakang tempat penyimpanan yang berjarak 30 meter

5. Stasiun $\mathrm{V}$ berada tepat di belakang tempat penyimpanan yang berjarak 45 meter

6. Stasiun VI berada di samping kanan tempat penyimpanan berjarak 50 meter dari tempat penyimpanan tersebut

7. Stasiun VII berada di samping kanan tempat penyimpanan berjarak 70 meter dari tempat penyimpanan tersebut.

8. Stasiun VIII berada di samping kanan tempat penyimpanan berjarak 80 meter dari tempat penyimpanan tersebut

9. Stasiun IX berada di Jalan Nusantara sebelah kiri tempat penyimpanan yang berjarak 100 meter dari tempat penyimpanan tersebut

10. Stasiun $\mathrm{X}$ berada di sebelah belakang stasiun IX berjarak 110 meter dari tempat penyimpanan tersebut.

11. Stasiun XI berada di radius 150 meter dari tempat penyimpanan

12. Stasiun XII di sebelah kiri Stasiun XI yang berjarak 10 meter atau $160 \mathrm{~m}$ dari tempat penyimpanan

13. Stasiun XIII berada di sebelah kiri stasiun XII yang berjarak 20 meter dari stasiun XII

14. Stasiun XIV lokasi terjauh dari gudang penyimpanan yang berjarak 175 meter dari gudang penyimpanan.

Pengambilan sampel air sumur dilakukan dengan ulangan sebanyak 2 (dua) kali dengan selang waktu 1 minggu. Parameter yang digunakan yaitu parameter fisik (bau, rasa, dan total zat padat terlarut), kimia $\left(\mathrm{CaCO}_{3}, \mathrm{pH}\right.$, Klorida, Sulfat, Besi, Mangan) dan biologi (Total Coliform atau Coliform Fecal) sesuai dengan PERMENKES No. 416/MENKES/PER/IX/1990 Tentang Syarat syarat dan Pengawasan Kualitas Air.

Pengambilan sampel perilaku masyarakat (pengetahuan, sikap dan praktik) diambil dengan teknik Purposive Sampling. Masyarakat sebagai responden di Kelurahan Karangtalun adalah warga masyarakat yang dipilih berdasarkan lokasi tempat tinggalnya pada radius $5 \mathrm{~m}$ hingga $250 \mathrm{~m}$ dari 
Gudang penyimpanan, terutama warga Kelurahan Karangtalun RT 3 dan RW 1 yang paling dekat dengan gudang tersebut serta telah lama bertempat tinggal pada lokasi tersebut lebih dari 2 tahun dan juga memanfaatkan air sumur tersebut untuk kebutuhan sehari-hari.

\subsection{Variabel Penelitian dan Prosedur Pengukuran}

\subsubsection{Kualitas Air Sumur}

Kualitas air terdiri atas beberapa parameter diantaranya fisika (bau, rasa, Total Dissolved Solid), Kimia (Kesadahan, pH, Klorida, Besi, Mangan, Sulfat) dan biologi (Total Coliform).

\section{a. Prosedur Pengukuran Kualitas Air Parameter Fisika}

1) $\mathrm{Bau}$

Bau diukur langsung dengan bantuan organoleptik yaitu 5 orang pengamat yang terdiri atas seorang peneliti, 2 orang warga setempat dan 2 staff laboratorium analisis kualitas air, kemudian hasilnya dicatat dan dikelompokkan menjadi berbau atau tidak berbau.

2) Rasa

Rasa diukur langsung dengan bantuan organoleptik yaitu 5 orang pengamat yang terdiri atas seorang peneliti, 2 orang warga setempat dan 2 staff laboratorium analisis kualitas air dan kemudian hasilnya dicatat serta dikelompokkan menjadi berasa atau tidak berasa.

3) Total Dissolved Solid (TDS)

Prinsip dasar TDS adalah penguapan contoh uji yang sudah disaring dengan kertas saring berpori $2 \mu \mathrm{m}$ pada suhu $180{ }^{\circ} \mathrm{C}$ kemudian ditimbang sampai berat tetap.

\section{b. Prosedur Pengukuran Kualitas Air Parameter Kimia}

1) Kesadahan

Pemeriksaan Kesadahan total menggunakan metode kompleksometri ( SNI 06-6989.122004).

2) $\mathrm{pH}$

Nilai $\mathrm{pH}$ diukur dengan menggunakan $\mathrm{pH}$ meter universal (metode Kalorimeter) atau dengan menggunakan $\mathrm{pH}$ meter digital. 
3) Klorida

$$
\mathrm{NAgNO}_{3}=\frac{\mathrm{V}_{1} \times \mathrm{N}_{1}}{\mathrm{~V}_{\mathrm{A}}-\mathrm{V}_{\mathrm{B}}}
$$

4) Sulfat $\left(\mathrm{SO}_{4}{ }^{2-}\right)$

Ion sulfat bereaksi dengan barium klorida dalam suasana asam akan membentuk suspensi barium sulfat dengan membentuk kristal barium sulfat yang sama besarnya diukur dengan spektrofotometer dengan panjang gelombang $420 \mathrm{~nm}$.

5) $\operatorname{Besi}(\mathrm{Fe})$

Metode ini digunakan untuk penentuan logam besi (Fe) total dan terlarut dalam air dan air limbah secara spektofotometri serapan atom-nyala (SSA) pada kisaran kadar Fe 0,3 $\mathrm{mg} / \mathrm{L}$ sampai dengan $10 \mathrm{mg} / \mathrm{L}$ dengan panjang gelombang 248,3 $\mathrm{nm}$ sesuai dengan $\mathrm{SNI}$ 6989.4:2009.

$\mathrm{A}=\mathrm{ax}+\mathrm{b}$

6) Mangan (Mn)

Metode ini digunakan untuk penentuan logam mangan (Mn) total dan terlarut dalam air dan air limbah secara spektofotometri serapan atom-nyala (SSA) pada kisaran kadar Mn 0,1 mg/L sampai dengan $10 \mathrm{mg} / \mathrm{L}$ dengan panjang gelombang 279,5 $\mathrm{nm}$ sesuai dengan SNI 6989.5:2009.

\section{c. Prosedur Pengukuran Kualitas Air Parameter Biologi}

(Ruyitno, 1997)

\subsubsection{Perilaku Masyarakat}

a.Variabel perilaku masyarakat dalam penelitian ini diidentifikasi melalui indicator pengetahuan, sikap dan tindakan

b. Prosedur pengukuran perilaku masyarakat dilakukan dalam skala ordinal terhadap indikator pengetahuan sebagai berikut : 


\section{Pengetahuan}

Pengetahuan merupakan suatu proses "tahu", dan ini terjadi setelah orang melakukan penginderaan terhadap suatu objek tertentu (Notoatmodjo, 2003). Pengetahuan kesehatan adalah suatu proses "tahu" terhadap suatu objek yang memberi pengaruh atau dampak kesehatan melalui proses penginderaan. Pengetahuan masyarakat Kel. Karangtalun atau responden mengenai kesehatan terhadap adanya bangunan gudang kapur dapat diukur melalui indikator - indikator pengetahuannya yang antara lain : lingkungan hidup bersih, sampah, sumur gali, pencemaran, kesehatan. Pengukuran pengetahuan responden tersebut dilakukan dengan pengskoran terhadap indikator - indikator pengetahuannya.

\section{Sikap}

Sikap merupakan respons ataupun reaksi seseorang yang masih tertutup terhadap suatu stimulus atau objek. Menurut Notoatmodjo (2003), sikap yang utuh (total attitude) terbentuk akibat kepercayaan (keyakinan), ide, konsep, dan kehidupan emosional (evaluasi emosional) terhadap suatu objek serta kecenderungan untuk bertindak. Sikap masyarakat di Kelurahan Karangtalun mengenai kesehatan terhadap dampak keberadaan gudang kapur dapat diukur melalui beberapa indikator seperti tanggapan terhadap keberadaan gudang kapur.

Pengukuran sikap atau tanggapan responden tersebut dilakukan dengan pengskoran terhadap beberapa indikator sikapnya dalam pertanyaan - pertanyaan dalam kuesioner.

\section{Tindakan}

Praktik atau atau tindakan merupakan suatu bentuk sikap yang terfasilitasi secara nyata (baik positif maupun negatif) terhadap suatu bentuk objek yang mempengaruhi seseorang. Berdasarkan Notoatmojo (2003), tindakan membutuhkan faktor pendukung (eksternal) seperti fasilitas atau suatu kondisi yang memungkinkan agar sikap dapat terwujud menjadi perbuatan nyata.

Tindakan yang terjadi pada masyarakat Kelurahan Karangtalun terhadap masalah kesehatan akibat keberadaan Gudang Kapur dapat berupa suatu tindakan positif. Tindakan positif masyarakat Kelurahan Karangtalun mengenai kesehatan terhadap 
dampak keberadaan Gudang Kapur dapat diukur melalui indikator - indikator tindakan antara lain : perbaikan kondisi lingkungan sekitarnya, perbaikan kondisi kesehatan.

\subsection{Analisis Data}

Data kualitas air sumur dibandingkan dengan ketentuan Menteri Kesehatan No. 416/PERMEN/1990 Tentang Syarat - Syarat dan Pengawasan Kualitas Air. Setelah itu, data tersebut dilakukan analisis lanjutan dengan menggunakan Metode Storet. Penilaian dilakukan berdasarkan sistem nilai dari US EPA (United States Environmental Protection Agency) dengan diklasifikasikan atas 4 kelas, yaitu, :

1) Kelas A : baik sekali, skor $=0 \rightarrow$ memenuhi baku mutu

2) Kelas B : baik, skor $=-1 \mathrm{~s} / \mathrm{d}-10 \rightarrow$ cemar ringan

3) Kelas $\mathrm{C}:$ sedang, skor $=-11 \mathrm{~s} / \mathrm{d}-30 \rightarrow$ cemar sedang

4) Kelas D : buruk, skor $\geq-31 \rightarrow$ cemar berat

Analisis data perilaku masyarakat dilakukan dengan menggunakan software SPSS (Statistical Product and Service Solution) for windows versi 17 untuk diperoleh suatu gambaran mengenai objek penelitian secara deskriptif berdasarkan data dan variable dari kelompok subjek yang diteliti dan kemudian ditampilkan dalam bentuk diagram persentase distribusi frekuensi terhadap setiap variabel perilakunya. Selanjutnya dilakukan crosstabulations antara pengetahuan dan sikap terhadap tindakannya untuk diperoleh pembentuk perilakunya. Data tersebut kemudian dilakukan deskripsi secara kualitatif berdasarkan hubungan antara kualitas air dengan pembentuk perilaku kesehatan (pengetahuan, sikap dan tindakan) masyarakatnya mengenai keberadaan Tempat Penyimpanan / Gudang Kapur.

Analisis hubungan perilaku masyarakat dengan kualitas air sumur gali dilakukan dengan menggunakan software SPSS (Statistical Product and Service Solution) for windows versi 17

\section{HASIL DAN PEMBAHASAN}

\subsection{Deskripsi Lokasi Penelitian}

Kelurahan Karangtalun terletak di Kecamatan Cilacap Utara yang memiliki empat batas wilayah yang meliputi Kelurahan Kali Donan disebelah Utara; Kelurahan Kebonmanis disebelah Selatan; Kelurahan Lomanis disebelah Barat; Kelurahan Tritih Kulon disebelah Timur. Berdasarkan kondisi geografisya, Kelurahan Karangtalun memiliki ketinggian tanah 6 m di atas permukaan laut. Dengan 
luas 353,02 Ha atau sekitar $19 \%$ luas kecamatan Cilacap Utara. Jarak dari pusat pemerintah kecamatan 4,5 km. Kelurahan Karangtalun mempunyai sifat iklim tropis dengan musim penghujan dan kemarau yang silih berganti selama satu tahun. Curah hujan rata - rata 2000 - $3000 \mathrm{~mm}$ dan suhu udara rata - rata $26^{\circ} \mathrm{C}$.

Jumlah Penduduk Kelurahan Karangtalun terdiri atas 11.143 orang yang terdiri atas 2.786 kepala keluarga (KK) dengan persentase perkembangan sebesar 0,76\% (pada awal tahun 2012).

\subsection{Kualitas Air Sumur Berkaitan dengan Keberadaan Tempat Penyimpanan Kapur}

Pengukuran parameter kualitas air dilakukan terhadap parameter bau, rasa, padatan total terlarut (TDS), kekeruhan, $\mathrm{pH}, \mathrm{CaCO}_{3}$, besi, mangan, klorida, sulfat, Total Coliform. Hasil rata - rata pengukuran kualitas air pada seluruh stasiun pengamatan sebagai berikut :

Hasil pengukuran parameter bau terlihat bahwa kualitas air pada stasiun I dan V berbau. Bau yang dijumpai pada Stasiun I dan V diindikasikan oleh karena adanya aktivitas bakteri yang masuk ke dalam sumur. Darmono (2001) mengemukakan pula bahwa bau air dapat pula disebabkan oleh beberapa faktor seperti mikroorganisme akuatik perairan, effluent rumah tangga, industri maupun tempat pengelolaan sampah.

Hasil pengukuran parameter rasa menunjukkan hasil yang tidak selaras dengan parameter bau, di mana seluruh stasiun tidak menimbulkan rasa dalam air yang diukur. Air yang normal seharusnya tidak memiliki rasa, air yang berasa dapat terjadi dikarenakan terdapat penyimpangan yang diakibatkan oleh adanya introduksi bahan asing atau kontaminan. Fardiaz (1992) dan Wardhana (2001) mengemukakan bahwa air yang tidak normal umumnya memiliki rasa yang tidak normal dan bau yang tidak normal pula selain itu air yang digunakan untuk kehidupan seharusnya tidak berasa, berbau, dan berwarna.

Hasil pengukuran TDS (Total Dissolved Solid) menunjukkan nilai yang tinggi pada Stasiun I dan V yaitu 1202,04 mg/L dan 1101,14 mg/L. Permenkes No. 416 Tahun 1990 mensyaratkan kadar TDS maksimal adalah 1000 mg/L. Fardiaz (1992) menyatakan bahwa peningkatan nilai TDS pada perairan sangat dipengaruhi oleh pelapukan batuan, limpasan tanah, dan pengaruh antropogenik (limbah domestik).

Hasil pengukuran parameter $\mathrm{pH}$ menujukkan derajat kemasaman yang relatif basa berkisar di range 7 - 7,9 di seluruh stasiun penelitian. $\mathrm{pH}$ merupakan suatu parameter penting untuk menentukan 
kadar asam / basa dalam air. Perubahan $\mathrm{pH}$ air dapat menyebabkan berubahnya bau, rasa dan warna. Air minum sebaiknya memiliki pH netral, tidak asam maupun basa, untuk mencegah terjadinya pelarutan logam berat dan korosi jaringan distribusi air minum (Effendi, 2003). Baku Mutu Air yang terdapat pada Permenkes No. 416 Tahun 1990 menentukan konsentrasi toleransi terhadap pH untuk peruntukkannya yaitu pada rentang 6 - 8,5. Derajat kemasaman pada seluruh stasiun penelitian berdasarkan Permenkes No. 416 Tahun 1990 dapat dinyatakan masih dalam batas toleransi sesuai peruntukkannya.

Hasil pengukuran parameter kekeruhan di stasiun XIII 11,77 NTU sedangkan baku mutu air yang terdapat di Permenkes No. 416 Tahun 1990 menentukan konsentrasi kekeruhan tidak melebihi 5 NTU. Kekeruhan menggambarkan sifat optik air yang ditentukan berdasarkan banyaknya cahaya yang diserap dan dipancarkan oleh bahan - bahan yang terdapat di dalam air. Kekeruhan disebabkan adanya bahan organik dan anorganik yang tersuspensi dan terlarut, maupun bahan anorganik dan organik yang berupa plankton dan mikroorganisme lain (Effendi, 2003).

Hasil pengukuran kesadahan menunjukkan bahwa beberapa stasiun pengamatan memiliki kadar kesadahan yang melebihi baku mutu Permenkes No. 416 Tahun 1990 yaitu stasiun pengamatan I dan V dengan konsentrasi masing - masing sebesar 714,67 mg/L dan 534,33 mg/L. Tingginya konsentrasi di Stasiun pengamatan I menunjukkan bahwa lokasi tersebut terdekat dengan tempat penyimpanan / gudang kapur. Batu kapur (limestone), adalah sedimen yang banyak mengandung organisme laut yang telah mati yang berubah menjadi kalsium karbonat. Batuan ini merupakan hasil penumpukan dan sedimentasi ribuan tahun yang lalu, membentuk bebatuan masif berwarna putih kekuningan sampai kecoklatan. Mineral murni batu kapur mengandung $\mathrm{CaCO}_{3}$ sebagai kalsit (Nukman, 2005). Sehingga stasiun pengamatan I yang paling dekat dengan tempat penyimpanan tersebut memiliki nilai tertinggi.

Hasil pengukuran besi $(\mathrm{Fe})$ mengalami peningkatan signifikan terutama pada Stasiun XIII dengan konsentrasi sebesar 1,47 mg/L. Konsentrasi besi dibatasi maksimum $1 \mathrm{mg} / \mathrm{L}$ dikarenakan jika kelebihan zat Fe dapat menyebabkan keracunan, dimana terjadi muntah, diare dan kerusakan usus (Ni Made, 2008). Selain masalah kesehatan alasan lainnya adalah masalah warna, rasa serta timbulnya kerak yang menempel pada system perpipaan atau alasan estetika lainnya (Idaman, 2005).

Hasil pengukuran mangan (Mn) mengalami kecenderungan menurun, dimana pada stasiun $\mathrm{V}$ justru terlihat paling tinggi diantara stasiun lainnya, dengan konsetrasi $1,17 \mathrm{mg} / \mathrm{L}$ sementara pada baku 
mutu disyaratkan konsentrasi maksimalnya adalah $0,1 \mathrm{mg} / \mathrm{L}$. Penetapan standar (baku mutu) tersebut ditetapkan berdasarkan kenyataan bahwa besi dan mangan di dalam air dapat menimbulkan bau dan rasa yang tidak sedap. Di dalam tubuh manusia, mangan dalam jumlah yang kecil tidak menimbulkan gangguan kesehatan, tetapi dalam jumlah yang besar dapat tertimbun di dalam hati dan ginjal (Idaman, 2005).

Hasil pengukuran parameter klorida $(\mathrm{Cl})$ menunjukkan bahwa di seluruh stasiun pengamatan konsentrasi klorida masih jauh di bawah baku mutu yang ditetapkan sesuai dengan Permenkes no. 416 Tahun 1990 sebesar 600mg/L. Klorida terdapat di alam dengan konsentrasi yang beragam. Kadar klorida umumnya meningkat seiring dengan meningkatnya kadar mineral. Kadar klorida yang tinggi, yang diikuti oleh kadar kalsium dan magnesium yang juga tinggi, dapat meningkatkan sifat korosivitas air. Hal ini mengakibatkan terjadinya perkaratan logam (Effendi, 2003).

Hasil pengukuran total Coliform menunjukkan bahwa pada stasiun pengamatan memiliki kecenderungan meningkat karena adanya aktivitas domestik di sekitarnya. Menurut Fardiaz (1992) dan Yu (2000), jumlah Total Coliform yang tinggi dapat terjadi akibat tingginya kontaminasi bakteria patogenik yang berasal dari saluran pencernaan manusia maupun hewan dan agen patogenik lainnya.

Hasil pengukuran parameter kualitas air sumur dapat pula ditentukan status mutunya dengan menggunakan Metode Storet. Metode ini digunakan untuk mengetahui parameter-parameter yang telah memenuhi ataupun yang melampaui baku mutu air yang telah ditentukan oleh peraturan yang berlaku. Berdasarkan hasil perhitungan dengan Metode Storet terhadap empat belas stasiun pengamatan, diperoleh skor yaitu : Stasiun I = -54 (Cemar Berat); Stasiun II = -24 (Cemar Sedang); Stasiun III = -6 (Cemar ringan); Stasiun IV = 0 (memenuhi baku mutu); Stasiun V = -50 (Cemar Berat); Stasiun VI = 0 (memenuhi baku mutu); Stasiun VII = 0 (memenuhi baku mutu); Stasiun VIII = -24 (cemar sedang); Stasiun IX = -30 (cemar sedang); Stasiun X = -24 (cemar sedang); Stasiun XI = 0 (memenuhi baku mutu); Stasiun XII = -24 (cemar sedang); Stasiun XIII = -60 (cemar berat); Stasiun XIV = -24 (cemar sedang).

Hasil tersebut menunjukkan bahwa secara umum Sumur warga Kelurahan Karangtalun telah mengalami pencemaran yang terlampau tinggi, terutama pada Stasiun I, V dan XIII yang terintroduksi langsung oleh bahan pencemar kapur. Pencemaran pada Stasiun I yang tinggi merupakan lokasi terdekat dari tempat penyimpanan gudang kapur. 


\subsection{Perilaku Masyarakat Berkaitan dengan Keberadaan Tempat Penyimpanan Kapur}

\subsubsection{Pengetahuan}

Pengetahuan yang dimiliki oleh masyarakat di Kelurahan Karangtalun diperoleh sebesar 5,1\% responden memiliki pengetahuan yang rendah, 87,2\% responden memiliki pengetahuan yang sedang dan 7,7\% responden memiliki pengetahuan yang tinggi. Pengetahuan yang dimiliki oleh responden dapat dipengaruhi oleh pendidikan, pekerjaan dan umur. Pendidikan berarti bimbingan yang diberikan oleh seseorang kepada orang lain agar mereka dapat memahami. Semakin tinggi pendidikan seseorang makin mudah pula bagi mereka untuk menerima informasi dan pada akhirnya makin banyak pengetahuan yang mereka miliki (Notoatmodjo, 2007).

\subsubsection{Sikap}

Sikap masyarakat Kelurahan Karangtalun secara umum yaitu bersikap negatif berkaitan dengan sikap terhadap keberadaan tempat penyimpanan / gudang kapur, dimana diperoleh dari hasil kuesioner sebesar 83\% responden bersikap negatif, 12\% responden bersikap netral dan 5\% responden bersikap positif. Sikap yang dilakukan oleh masyarakat Kelurahan Karangtalun terhadap keberadaan tempat penyimpanan (gudang) kapur dikarenakan masyarakat tidak bisa menggunakan kembali air sumur yang menjadi andalan di Kelurahan Karangtalun dimana sikap merupakan bentuk respon tertutup terhadap stimulus atau objek tertentu, yang sudah melibatkan faktor pendapat dan emosi yang bersangkutan (senang-tidak senang, setuju - tidak setuju, baik tidak baik dan sebagainya) (Notoatmodjo, 2010).

\subsubsection{Tindakan}

Tindakan masyarakat Kelurahan Karangtalun pada umumnya bertindak aktif berkenaan dengan tindakan tentang upaya perbaikan kondisi sumur terhadap keberadaan tempat penyimpanan / gudang kapur, dimana diperoleh hasil kuesioner sebesar 84\% responden bertindak aktif, 15\% bertindak netral dan $1 \%$ bertindak pasif. Hal ini dikarenakan masyarakat Kelurahan Karangtalun yang berada disekitar tempat penyimpanan / gudang kapur cenderung melakukan tindakan dalam peningkatan maupun perbaikan kondisi sumur ataupun dengan penambahan sumber air baru.

Perilaku masyarakat yang terbentuk diawali oleh upaya memperoleh pengetahuan lalu membentuk sikap dan kemudian jika individu tersebut memiliki motivasi kemudian menghasilkan tindakan 
(praktik) yang berasal dari suatu respon masyarakat terhadap stimulus lingkungan yang mempengaruhinya.

Perilaku masyarakat yang terbentuk dalam masyarakat Kelurahan Karangtalun mengenai keberadaan tempat penyimpanan gudang kapur berdasarkan hasil cross tabulation atau tabulasi silang diperoleh sebanyak 1 orang atau $25 \%$ responden pengetahuan rendah bertindak lebih netral dan hanya 3 orang atau $75 \%$ responden berpengetahuan rendah lebih bertindak aktif. Sebanyak 1 orang atau $1,47 \%$ responden pengetahuan sedang bertindak pasif, 11 orang atau $16,18 \%$ responden pengetahuan sedang bertindak netral dan sebanyak 56 orang atau 82,35\% responden pengetahuan sedang lebih bertindak aktif. Sedangkan pengetahuan tinggi hanya 6 orang saja yang bertindak lebih aktif.

Hasil tabulasi silang tersebut menunjukkan bahwa sebagian besar masyarakat hanya memiliki pengetahuan sedang meskipun terdapat masyarakat memiliki pengetahuan tinggi dengan memperoleh berbagai informasi terkait dengan keberadaan tempat penyimpanan / gudang kapur dengan bentuk tindakan yang lebih ingin perbaikan kondisi sumur gali yang mereka miliki seperti sediakala. Hal ini dilakukan karena masyarakat di Kelurahan Karangtalun, Kecamatan Cilacap Utara, Kabupaten Cilacap, tidak semuanya mampu untuk membayar PDAM, sehingga mereka lebih memilih untuk menggunakan sumur.

Hasil tabulasi silang antara sikap dengan tindakan diperoleh bahwa 52 orang atau $80 \%$ responden memiliki sikap negatif akan bertindak lebih aktif. Sedangkan 9 orang atau $100 \%$ responden memiliki sikap netral dan bertindak aktif, namun 4 orang responden memiliki sikap positif akan lebih bertindak aktif. Sikap negatif terhadap keberadaan tempat penyimpanan kapur dengan tindakannya yang aktif tersebut menunjukkan bahwa responden secara langsung menyatakan tindakan setujunya.Hal ini dapat dilihat dari responden yang tidak ingin ada kelanjutan dari tempat penyimpanan atau gudang kapur tersebut.

\subsection{Hubungan Antara Kualitas Air Sumur Gali dan Perilaku Masyarakat Berkaitan dengan Keberadaan Tempat Penyimpanan Kapur}

Kualitas air sumur gali di Kelurahan Karangtalun, Kecamatan Cilacap Utara, Kabupaten Cilacap yang sebagian besar tercemar ringan dipengaruhi oleh aktifitas masyarakat disekitarnya.

Pengetahuan masyarakat yang sedang dan sikapnya yang cenderung tidak setuju menerima keberadaan tempat penyimpanan / gudang kapur tersebut berpengaruh pada perilaku masyarakat 
dalam memanfaatkan air sumur tersebut. Perilaku masyarakat terhadap keberadaan tempat penyimpanan / gudang kapur dipengaruhi oleh pengetahuan, sikap dan tindakan yang tercipta sebelumnya, sehingga masyarakat menginginkan tidak ada kelanjutan aktivitas di tempat penyimpanan / gudang kapur tersebut.

Hasil tabulasi silang antara perilaku masyarakat dengan kualitas air terhadap keberadaan tempat penyimpanan atau gudang kapur 1 orang responden berperilaku rendah memiliki kualitas air yang sesuai dengan baku mutu. Sedangkan 17 orang atau 23,94\% responden berperilaku sedang memiliki kualitas air sumur yang tercemar berat. Namun 4 orang atau 66,7\% responden berperilaku tinggi memiliki kualitas air sumur yang tercemar ringan.

Analisis Chi - Square digunakan untuk menguji hubungan atau pengaruh dua buah variabel nominal (Wiratna, 2014). Pearson Chi - Square Asymp. Sig =0,506. Sehingga 0,506 > 0,05 maka Ho diterima, yaitu tidak terdapat hubungan antara perilaku masyarakat dengan kualitas air.

\section{KESIMPULAN dan SARAN}

\subsection{KESIMPULAN}

1. Kualitas air sumur gali di Kelurahan Karangtalun tercemar ringan hingga tercemar berat, terutama pada Stasiun I, V dan XIII yang tidak memenuhi baku mutu untuk parameter fisik, kimia dan biologi. Total Coliform pada sebagian stasiun telah melampaui baku mutu yang dipersyaratkan sehingga stasiun tersebut berada pada kondisi "Cemar Berat".

2. Masyarakat Kelurahan Karangtalun memiliki pengetahuan yang cukup, bersikap negatif dan bertindak aktif terhadap keberadaan Tempat Penyimpaan / Gudang Kapur. Hal ini menyebabkan masyarakat Kelurahan Karangtalun secara umum berperilaku netral mengenai keberadaan Tempat Penyimpanan / Gudang Kapur.

3. Kualitas air sumur gali yang ada di Kelurahan Karangtalun, Kecamatan Cilacap Utara, Kabupaten Cilacap sebagian besar tercemar sedang dan perilaku masyarakat yang ada cenderung netral. Hasil analisa Chi - Square menunjukkan bahwa Sig. > 0.05 sehingga Ho ditolak, dalam artian bahwa antara kualitas air sumur gali dengan perilaku masyarakat tidak ada hubungan. 


\subsection{SARAN}

1. Kajian kualitas air sumur gali sebaiknya dilakukan pula pada musim hujan untuk diperoleh perbandingan hasil pengamatan di lokasi yang sama.

2. Kualitas stasiun yang berada pada kondisi tercemar berat diharapkan untuk tidak dikonsumsi oleh masyarakat sekitar.

\section{DAFTAR PUSTAKA}

Asmadi, Khayan, dan Kasjono, H.S. 2011. Teknologi Pengolahan Air Bersih. Gosyen Publishing, Yogyakarta.

Badan Standardisasi Nasional (BSN), 2002. Standar Nasional Indonesia : Standar Pengujian Total Padatan Terlarut dengan Metode Gravimetri. Badan Standardisasi Nasional, Jakarta. ,2004. Standar Nasional Indonesia : Standar Pengujian Kesadahan Total Kalsium (Ca) dan Magnesium (mg) Dengan Metode Titrimetri. Badan Standardisasi Nasional, Jakarta.

,2004. Standar Nasional Indonesia : Standar Pengujian

Klorida $\left(\mathrm{Cl}^{-}\right)$Dengan Metode Argentometri. Badan Standardisasi Nasional, Jakarta.

,2004. Standar Nasional Indonesia : Standar Pengujian Sulfat $\left(\mathrm{SO}^{2-}{ }^{2-}\right.$ Dengan Metode Turbidimetri. Badan Standardisasi Nasional, Jakarta.

,2005. Standar Nasional Indonesia : Standar Pengujian Kadar

Mangan (Mn) Dengan Metode Spektofotometer Serapan Atom (SSA). Badan Standardisasi Nasional, Jakarta.

2005. Standar Nasional Indonesia : Standar Pengujian Besi

(Fe) Dengan Metode Spektofotometer Serapan Atom (SSA). Badan Standardisasi Nasional, Jakarta.

Bertschinger, P. 2006. Laporan Pelaksanaan RKL dan RPL PT Holcim Indonesia. Tbk Pabrik Narogong. Bogor.

Darmono. 2001. Lingkungan Hidup dan Pencemaran: Hubungan dengan Toksikologi Senyawa Logam. Universitas Indonesia, Jakarta.

Effendi, H. 2003. Telaah Kualitas Air : Bagi Pengelolaan Sumber Daya dan Lingkungan Perairan. Kanisius, Yogyakarta.

Fardiaz, S. 1992. Polusi Air dan Udara. Cetakan Ketiga Belas. Kanisius, Yogyakarta. 
Harmayani, K.D. dan Konsukartha, I.G.M. 2007. Pencemaran Air Tanah Akibat Pembuangan Limbah Domestik di Lingkungan Kumuh. Jurnal Pemukiman Natah, Vol. 5, No. 2: 62-108 Idaman, Nusa Said. 2005. Metoda Penghilang Zat Besi di Dalam Penyediaan Air Minum Domestik. (On-line) http://ejurnal.bppt.go.id/index.php/JAI/article/view/47/46 diakses 26 Oktober 2014

Notoatmodjo, S. 2003. Prinsip-prinsip Dasar Ilmu Kesehatan Masyarakat. Cetakan Kedua. PT Rineka Cipta, Jakarta. 2007. Promosi Kesehatan dan Ilmu Perilaku. Rineka Cipta, Jakarta. . 2010. Ilmu Perilaku Kesehatan. Rineka Cipta, Jakarta

PT. Holchim Indonesia Tbk, 2010, Laporan Pembangunan Berkelanjutan. (On-line) http://www.geocycle.co.id/fileadmin/templates/GEOCYCLE_ID/doc/2010_HIL_SD_ID.pdf diakses 23 April 2014

Peraturan Menteri Kesehatan Republik Indonesia No. 416 Tahun 1990 Tentang Syarat - Syarat dan Pengawasan Kualitas Air.

Sutrisno, T., 2004. Teknologi Penyediaan Air Bersih, PT Rineka Cipta, Jakarta.

Undang Undang Nomor 32 Tahun 2008 tentang Perlindungan dan Pengelolaan Lingkungan Hidup. Kementrian Lingkungan Hidup Republik Indonesia. Jakarta.

Wardhana, W.A. 2001. Dampak Pencemaran Lingkungan. ANDI, Yogyakarta.

Wiratna, V. Sujarweni, 2014. SPSS Untuk Penelitian. Pustaka Baru Press, Yogyakarta.

Yu, M. H. 2001. Environmental Toxicology: Impacts of Environmental Toxicants on Living Systems. CRC Press LLC, California. 